\title{
Peertechz
}

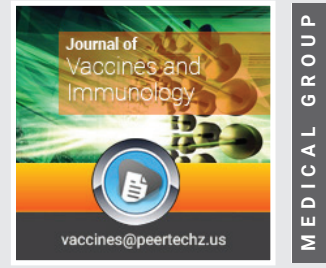

\section{COVID-19 IGG better than PCR for the green pass}

\author{
Damsa Cristian* and Damsa Tomas \\ MD, Department of Psychiatry, IMH SA 17 rte de la Chapelle 1212 Grand Lancy, Switzerland
}

Received: 14 July, 2021

Published: 20 July, 202

*Corresponding author: Damsa Cristian, MD, Department of Psychiatry, IMH SA 17 rte de la Chapelle 1212 Grand Lancy, Switzerland, Tel: 0041762719996; Fax: 0041225341612; E-mail: c.damsa@bluewin.ch ORCID: https://orcid.org/0000-0003-1900-3220 Keywords: COVID-19; IGG; PCR; Green pass https://www.peertechzpublications.com

\section{Check for updates}

European Countries and Switzerland provide Green Pass for people who fulfill the two doses' vaccines but also for people who recovered from COVID-19. In order to prove that people recovered they should provide a positive PCR from more than two weeks ago, while IGG positive for COVID-19 is not accepted as a prove of recovery. This policy is not sustained by evidence-based medicine. The proportion of re-positive tests in discharged COVID-19 patients varied from 2.4 to $69.2 \%$ and persisted from 1 to 38 days after discharge, depending on population size, age of patients, and type of specimens [1-3]. Many causes of re-positive tests for SARS-CoV-2 in recovered COVID-19 patients are suggested, including false-negative, false-positive RT-PCR tests, reactivation and re-infection, but the mechanism leading to these re-positive cases is unclear. Therefore, it is weird to consider people that recovered after only two weeks following a positive PCR, without any other tests. IGG COVID-19 positive have a strong specificity around 99 to $100 \%$ [4] and IGG appears after around one month post COVID-19 which seems to be linked to a lower risk to be contagious comparing to only two weeks after the positive PCR. Moreover, the presence of IGG of COVID-19 is linked to a lower risk to develop again the disease rather than only a positive PCR, without any specific antibodies [5]. Taking into account those data, the politicians decided to bet on the positive PCR to deliver the green pass, without scientific data to sustain this decision, in spite of the strong specificity of the IGG, with a lower risk of re infection in case of IGG positive than PCR positive, with a lower risk to transmit the disease after one month's in IGG than only two weeks after the PCR. Moreover,
PCR are more expensive than the IGG and people receive automatically the Green Pass 10 days after the positive PCR, even if they are admitted in intensive care unit or even dead, which do not seem appropriate. The interest of this letter is to underline that the political decisions should be in concordance with evidence-based medicine data and sending the Pass only for people who ask for that. Giving the green pass automatically and only after positive PCR test but not after positive IGG COVID-19 appears to be in discordance with immunologic and epidemiological data.

\section{References}

1. Dao TL, Hoang VT, Gautret $P$ (2021) Recurrence of SARS-CoV-2 viral RNA in recovered COVID-19 patients: a narrative review. Eur J Clin Microbiol Infect Dis 40: 13-25. Link: https://bit.ly/2USCKtW

2. Priyanka, Choudhary OP, Singh I, Patra G (2020) Aerosol transmission of SARS-CoV-2: The unresolved paradox. Trav Med Infec Dis 37: 101869. Link: https://bit.ly/3fuxQtT

3. Priyanka, Choudhary OP, Singh I (2021) Protective immunity against COVID-19: Unravelling the evidences for humoral vs. cellular components. Travel Med Infect Dis 39: 101911. Link: https://bit.ly/3hHUVMt

4. Paiva KJ, Grisson RD, Chan PA, Huard RC, Caliendo AM, et al. (2021) Validation and performance comparison of three SARS-CoV-2 antibody assays Comparative Study. J Med Virol 93: 916-923. Link: https://bit.ly/3in3dYO

5. Moretti M, Van Laethem J, De Geyter D, Cools W, Ilsen B, et al. (2021) Diagnostic accuracy of screening tests for patients suspected of COVID-19, a retrospective cohort study. Infect Dis (Lond) 1-10. Link: https://bit.ly/2Uq9kTZ

Copyright: ๑ 2021 Cristian D, et al. This is an open-access article distributed under the terms of the Creative Commons Attribution License, which permits unrestricted use, distribution, and reproduction in any medium, provided the original author and source are credited. 